REFLEKSI HUKUM

Jurnal Ilmu Hukum
p-ISSN 2541-4984 | e-ISSN 2541-5417

Volume 4 Nomor 1, Oktober 2019, Halaman 61-76

DOI: https://doi.org/10.24246/jrh.2019.v4.i1.p61-76

Open access at: http://ejournal.uksw.edu/refleksihukum

Penerbit: Fakultas Hukum Universitas Kristen Satya Wacana

\title{
UPAYA KEPOLISIAN RESOR HALMAHERA UTARA DALAM MENANGGULANGI KEJAHATAN NARKOTIKA KABUPATEN HALMAHERA UTARA
}

\author{
Ernest Sengi \\ Fakultas Ilmu Sosial dan Humaniora Universitas Halmahera \\ Korespondensi: ernestsengi@gmail.com
}

\begin{abstract}
Abstrak
Wilayah yang berhadapan langsung dengan lautan pasifik dan dikelilingi pulau-pulau kecil menjadikan sasaran potensial masuknya narkotika di Halmahera Utara. Dalam tulisan ini, isu hukum yang dikaji adalah bagaimana upaya Kepolisian Resor Halmahera Utara dalam menanggulangi kejahatan narkotika di wilayahnya. Kemudian, untuk menjawab isu hukum tersebut digunakan pendekatan sosiologis meskipun didukung dengan pendekatan undangundang. Pendekatan ini tepat untuk menilai bagaimana upaya Kepolisian Halmahera Utara dalam menanggulangi kejahatan narkotika dan apakah regulasi terkait narkotika mendukung peran kepolisian. Hasil penelitian menunjukan terdapat 23 orang tersangka ditangkap dengan 12 jumlah kasus narkotika. Selain itu, upaya pencegahan dilakukan melalui patroli serta razia tempat nongkrong, kendaraan dan sosialisasi bahaya narkotika. Sementara itu, penghambat penegakan hukum kejahatan narkotika di Halmahera Utara: pertama, personil kepolisian yang berjumlah hanya 25 orang dengan jumlah penyidik dua (2) orang; kedua, sarana dan fasilitas yang kurang memadai; ketiga, seringkali terjadi kebocoran informasi sebelum razia dilakukan.
\end{abstract}

Kata Kunci: Narkotika; Halmahera Utara; Kepolisian.

\begin{abstract}
Territory that is directly facing the pacific ocean and surrounded by small islands becomes a potential target for receiving narcotics in North Halmahera. This paper discusses a legal issue about the role of the North Halmahera Police in overcoming narcotics crimes in their region. In order to answer the legal issue, a sociological approach and a statute approach were used. These approaches are appropriate for assessing the role of the North Halmahera Police in tackling narcotics crimes and to answer whether regulations on drugs has supported the role of the police or not. The result of the research showed that there were 23 suspects who were arrested with 12 narcotics cases. However, the preventive efforts were carried out through patrols and raids on hangouts, vehicles, and narcotics hazard awareness socialization. It is found that some inhibitors of narcotics crime law enforcement exist in North Halmahera: first, the number of police personnel only reached 25 people with 2 investigators; second, another problem came from inadequate facilities issue; third, information leakage often occurred before raids were carried out.
\end{abstract}

Keywords: Narcotics; North Halmahera; Police. 


\section{PENDAHULUAN}

Pembahasan mengenai kejahatan narkotika bukanlah merupakan hal baru dalam dunia praktek hukum maupun dalam dunia akademik. Namun, kejahatan narkotika selalu saja menjadi pembahasan yang tidak pernah bisa berhenti didiskusikan. Selain karena kejahatan narkotika merupakan kejahatan luar biasa (exstra ordinary crime), ${ }^{1}$ kejahatan narkotika juga mengancam keberadaan kehidupan generasi bangsa sehingga terus menerus dicari pendekatan yang tepat guna memberantas atau paling tidak meminimalisir terjadinya kejahatan ini.

Disadari atau tidak, kehidupan modern membawa paradigma baru dan berpengaruh pada pola hidup manusia dewasa ini. Hal ini terlihat pada tingginya tingkat kesibukan manusia, tingginya depresi, banyak anak-anak yang kurang mendapat perhatian orang tua karena masingmasing sibuk sendiri-sendiri, dan begitu padatnya kegiatan manusia bahkan sampai pada jam-jam malam misalnya terlihat pada banyaknya tempat-tempat kerja yang beroperasi pada malam hari. Hal ini menurut Julianan $^{2}$ sering menjadi celah dan potensi terjadi berbagai kejahatan narkotika dan obat-obatan terlarang. Sejalan dengan hal tersebut, Fromm dalam tulisan Elviza Rahmadona menyebut bahwa semakin manusia merasa bebas, manusia semakin merasakan kesepian dan keterasingan sehingga dapat melakukan berbagai tindakan negatif. ${ }^{3}$

Negara sebagai organ pelindung masyarakat harus mengikuti perkembangan zaman tersebut. Salah satu hal yang dilakukan negara adalah memberikan perlindungan hukum agar masyarakat dalam melakukan aktifitasnya tidak keluar dari jalur yang ditentukan apalagi sampai menggunakan narkotika. Atas dasar itu, Pemerintah Republik Indonesia mengeluarkan Undang-Undang Nomor 35 Tahun 2009 tentang Narkotika (UU Narkotika) sebagai bentuk perlindungan negara terhadap masyarakat. Sejalan dengan hal tersebut J.E. Sahetapy dalam Abdul Wahid mengatakan bahwa kejahatan erat kaitannya dan bahkan menjadi sebagian dari hasil budaya itu sendiri. ${ }^{4}$ Ini berarti semakin tinggi tingkat budaya dan semakin modern suatu bangsa, maka semakin modern pula kejahatan itu baik bentuk, sifat dan cara pelaksanaannya. Dengan demikian, peran negara penting dalam mengikuti perkembangan dimaksud terutama perkembangan kejahatan narkotika.

Peredaran narkotika tidak hanya tersebar di kota-kota besar tetapi juga sudah masuk sampai ke kota-kota kecil termasuk di wilayah Kabupaten Halmahera Utara. Narkotika juga telah merasuk pada hampir semua level dan profesi masyarakat baik pejabat, Pegawai Negeri Sipil (PNS), wiraswasta, pelajar bahkan sampai ke ibu-ibu rumah tangga (IRT).

Anton Sudanto, 'Penerapan Hukum Pidana Narkotika di Indonesia' (2017) 8 (1) ADIL: Jurnal Hukum 138, 140.

2 Julianan Lisa FR, Nengah Sutrisna W, Narkotika, Psikotropika dan Gangguan Jiwa (Nuha Medika 2013) 2.

3 Elviza Rahmadona dan Helfi Agustin, 'Faktor yang Berhubungan dengan Penyalahgunaan Narkoba di RSJ. HB. Sa'anin' (2014) 8 (2) Jurnal Kesehatan Masyarakat Andalas 60, 63.

$4 \quad$ Abdul Wahid, Kriminologi dan Kejahatan Kontemporer (Fakultas Hukum Unisma 2002) 21. 
Indonesia merupakan negara yang menjadi target peredaran narkotika paling potensial. Akses letak geografis Indonesia yang mudah dimasuki dari wilayah mana saja merupakan salah satu faktor berkembang cepatnya peredaran narkotika di Indonesia. Atas dasar itu semua warga dituntut untuk bekerja sama dalam penanggulangannya dan tidak hanya ditanggungkan kepada aparat penegak hukum. Dari data yang diperoleh Kementerian Komunikasi dan Informatika, hampir 50 (lima puluh) orang meninggal dunia setiap hari karena penyalahgunaan narkotika dan obat-obat terlarang. ${ }^{5}$ Selain itu, menurut Kepala Badan Narkotika Nasional (BNN) Provinsi Maluku Utara, Edi Swasono, tingkat prevalensi atau pecandu nakoba di Maluku Utara mencapai 13.500 orang dari 1,3 juta penduduk. ${ }^{6}$

Di Kabupaten Halmahera Utara dalam kurun waktu 5 (lima) tahun terakhir sudah 23 (dua puluh tiga) orang tersangka yang ditangkap dengan 12 (dua belas) jumlah kasus narkotika yang terjadi dan diproses oleh Kepolisian Resor (Polres) Halmahera Utara dimana pelakunya bervariasi mulai dari pejabat, pengusaha, PNS, pelajar dan IRT. Hal tersebut menunjukan bahwa kejahatan narkotika sudah masuk dalam wilayahwilayah kecil seperti Kabupaten Halmahera Utara meskipun kuantitasnya belum terlalu membahayakan.

Narkotika merupakan kejahatan yang dapat merusak generasi bangsa. Dengan demikian pemberantasan dan pencegahannya perlu mendapat perhatian khusus bagi semua pihak lebih khusus negara. Atas dasar itu, semua institusi kepolisian dituntut untuk memiliki satuan yang khusus menangani kasus-kasus narkotika. Namun demikian, Polres Halmahera Utara hingga saat ini belum memiliki satuan narkoba dan hanya dibentuk unit narkoba yang kapasitasnya masih kecil yakni bernaung di bawah satuan reserse kriminal (satreskrim).

Dalam pelaksanaan tugas unit narkoba Polres Halmahera Utara tentunya tidak mudah menegakan hukum, dalam hal ini kejahatan narkotika karena terdapat banyak faktor yang mempengaruhinya dan kejahatan ini biasanya terstruktur dikerjakan dengan rapi dan sistematis dengan melibatkan banyak aktor termasuk kemungkinan keterlibatan aparat penegak hukum sendiri dapat terjadi. Oleh sebab itu, perlu kerja sama dari semua pihak termasuk peran serta masyarakat sehingga kewenangan yang dimiliki aparat penegak hukum dalam hal ini kepolisian dapat maksimal dilakukan. Berdasarkan ide tersebut, penulis tertarik untuk meneliti dan menganalisis bagaimana upaya kepolisian khususnya unit narkotika Polres Halmahera Utara dalam menanggulangi kejahatan narkotika di wilayah hukum Polres Halmahera Utara.

Esensi suatu penelitian hukum adalah memberikan solusi pemecahan masalah hukum (legal problem solving) sehingga tidak salah apa yang

5 Anang Iskandar, 'BNN Ingatkan 50 Orang Meninggal Setiap Hari Karena Narkoba' (Kementrian Komunikasi dan Informatika Republik Indonesia, 30 April 2015) <https://kominfo.go.id/content /detail/4883/bnn-ingatkan-50-orang-meninggal-setiap-hari-karenanarkoba/0/sorotan_media> diakses 10 Juli 2019.

$6 \quad$ Olis, 'Kasus Narkoba di Maluku Utara Ibarat Gunung Es' (Kumparan, 31 Mei 2019 2019) <https://kumparan.com/ceritamalukuutara/kasus-narkoba-di-maluku-utara-ibarat-gunung-es -1rBeQnxGbt7>diakses 31 Mei 2019. 
dikatakan Peter Mahmud Marzuki bahwa penelitian hukum adalah suatu proses untuk menemukan aturan hukum, prinsip-prinsip hukum, maupun doktrin-doktrin hukum guna menjawab isu hukum yang dihadapi. ${ }^{7}$ Dalam tulisan ini, jenis penelitian hukum yang digunakan yakni penelitian hukum empiris. Bahder Johan Nasution menyebut bahwa penelitian hukum empiris bertujuan untuk mengetahui sejauh mana bekerjanya hukum dalam masyarakat. 8 Oleh karena penelitian ini merupakan penelitian empiris maka pendekatan yang digunakan yakni pendekatan sosiologis yang didukung dengan pendekatan perundang-undangan (statute approach). Kedua pendekatan tersebut dirasa tepat digunakan untuk menilai sejauh mana hukum bekerja di masyarakat dan apa faktor-faktor yang mempengaruhi bekerjanya hukum, dalam hal ini peraturan terkait narkotika di masyarakat.

Analisis hukum yang digunakan dalam penelitian ini adalah deskripsi, evaluasi dan argumentasi. Teknik ini bertujuan untuk menggambarkan secara mendalam mengenai upaya Polres Halmahera Utara dalam tugas dan tanggung jawabnya menanggulangi kejahatan narkotika. Kaitannya dengan penelitian ini, maka akan dilakukan analisis terhadap data primer khususnya data tindak pidana narkotika yang diperoleh dari unit narkoba reskrim Polres Halmahera Utara, kemudian mengaitkannya dengan data sekunder yakni bagaimana pengaturan terkait narkotika dalam UU Narkotika serta bagaimana peran kepolisian yang diatur dalam
UU No. 2 Tahun 2002 tentang Kepolisian (UU Kepolisian). Hal ini dilakukan agar dapat menggambarkan secara jelas mengenai upaya Polres Halmahera Utara selama ini dalam melakukan penindakan maupun pencegahan kejahatan narkotika di Kabupaten Halmahera Utara serta apa faktor penghambat dalam proses penegakan hukum.

\section{PEMBAHASAN}

\section{Pengaturan Terkait Kejahatan Narkotika}

Pengaturan terkait kejahatan narkotika di Indonesia sebetulnya sudah dimulai sejak zaman penjajahan. Psikotropika pertama kali diatur dalam Staatsblad 1949 No. 419 tanggal 22 Desember 1949 tentang Sterkwerendegeneesmiddelen Ordonantie yang kemudian diterjemahkan dengan Ordonansi Obat Keras. Jadi pertama kali psikotropika tidak diatur sendiri tetapi masih disatukan dengan bahan baku obat atau obat jadi lainnya yang termasuk obat keras (daftar G). Pada tanggal 2 April 1985 keluar Peraturan Menteri Kesehatan Republik Indonesia No. 213/Men.Kes/ Per/IV/1985 tentang Obat Keras Tertentu. Peraturan Menteri Kesehatan tersebut mencabut Keputusan Menteri Kesehatan RI No. 983/A/ SK/1971 dan Keputusan Menteri RI No. 10381/A/SK/1972. Kemudian pada tanggal 8 Februari 1993 dikeluarkan lagi Peraturan Menteri Kesehatan RI No. 124/Men.Kes/Per/ II.1993 tentang Obat Keras Tertentu

Peter Mahmud Marzuki, Penelitian Hukum (Cet. pertama, Kencana 2005) 35.

Bahder Johan Nasution, Metode Penelitian Ilmu Hukum (Cet. pertama, CV. Mandar Maju 2008) 123. 
yang merupakan perbaikan serta penambahan Peraturan Menteri Kesehatan RI terdahulu, dalam peraturan tersebut juga dilampiri Lampiran I dan Lampiran II, tetapi belum mencantumkan ketentuan pidana. Baru kemudian Tahun 1997, UU No. 22 Tahun 1997 tentang Narkotika diundangkan. Sebelum kelahiran UU ini tidak ada ketegasan dari segi hukum pidana mengenai tindak pidana psikotropika.

Ada beberapa revisi terhadap UU No. 22 Tahun 1997 tersebut. Hal ini karena masih ditemukan beberapa kelemahan selama pelaksanaan atau penerapannya sehingga UU ini akhirnya diperbaharui pada Tahun 2009 yang kemudian melahirkan UU Narkotika.

Pada zaman penjajahan Belanda kebiasaan penyalahgunaan obat bius dan candu, sudah mulai terasa membahayakan masyarakat, pemakainya terutama masyarakat golongan menengah (khususnya keturunan Cina). Oleh sebab itu, pada zaman tersebut pemerintah Hindia Belanda mengeluarkkan Verdoovende Middelen Ordonnantie, Staatsblad No. 278 Jo. 536 Tahun 1927, yaitu peraturan yang mengatur tentang obat bius dan candu. Selain itu, juga diberlakukan ketentuan mengenai pembungkusan candu yang disebut Opium verpakkings Bepalingen (Staatsblad No. 514 Tahun 1927). Setelah Indonesia merdeka, kedua instrumen hukum kolonial Belanda tersebut tetap diberlakukan berdasarkan Pasal II Aturan Peralihan Undang-Undang Dasar Negara Republik Indonesia Tahun 1945. Materi hukum peraturan perundang-undangan ini hanya mengatur mengenai perdagangan dan penggunaan narkotika, sedangkan tentang pemberian pelayanan kesehatan untuk usaha penyembuhan pecandunya tidak diatur.

Perkembangan kejahatan di bidang narkotika pasca masa kemerdekaan cenderung semaking meningkat dari tahun ke tahun, sehingga instrumen hukum yang mengatur tindak pidana narkotika warisan Belanda tersebut dirasakan sudah ketinggalan jaman. Oleh karena itu, pada tahun 1976 pemerintah menetapkan UU No. 8 Tahun 1976 tentang Pengesahan Konvensi Tunggal Narkotika 1961 beserta protokol perubahannya. Kemudian, menyusul diberlakukan UU No. 9 Tahun 1976 tentang Narkotika.

Ketidakpuasan akan pelaksanaan kegiatan penanggulangan narkotika dan obat-obat terlarang telah mengakibatkan bangsa Indonesia berpikir untuk menyempurnakan peraturan/ regulasi tentang narkotika karena Ordonansi Obat Bius (Verdoovende Middelen Ordonnantie, Staatsblad No. 278 Jo. 536 Tahun 1927) dirasa tidak lagi mampu untuk meredam pertumbuhan kejahatan narkotika. Dimana narkotika merupakan obat yang diperlukan dalam bidang pengobatan dan ilmu pengetahuan, yang diketahui dapat menimbulkan ketergantungan yang sangat merugikan apabila dipergunakan tanpa pembatasan dan pengawasan yang seksama.

Dengan pemikiran bahwa perbuatan, penyimpanan, pengedaran, dan penggunaan narkotika tanpa pembatasan dan pengawasan yang seksama merupakan kejahatan yang sangat merugikan perorangan dan masyarakat dan merupakan bahaya besar bagi perikehidupan menusia dan kehidupan negara di bidang politik, keamanan, sosial, budaya, serta ketahanan nasional bangsa Indonesia, 
maka terbitlah UU No. 9 Tahun 1976. UU ini mengatur cara penyediaan dan penggunaan narkotika untuk keperluan pengobatan dan atau ilmu pengetahuan; untuk mencegah dan menanggulangi bahaya-bahaya yang dapat ditimbulkan akibat samping dari penggunaan dan penyalahgunaan narkotika; serta untuk mengatur rehabilitasi terhadap pecandu narkotika.

Kejahatan narkotika yang merupakan bagian dari kejahatan terorganisasi, pada dasarnya termasuk salah satu kejahatan terhadap pembangunan dan kejahatan terhadap kesejahteraan sosial yang menjadi pusat perhatian dan keprihatinan nasional dan internasional. Hal itu sangat beralasan, mengingat ruang lingkup dan dimensinya begitu luas, sehingga kegiatannya mengandung ciri-ciri sebagai organized crime, whitecollar crime, corporate crime, dan transnational crime. Bahkan, dengan menggunakan sarana teknologi dapat menjadi salah satu bentuk dari cyber crime. Berdasarkan karakteristik yang demikian, maka dampak dan korban yang ditimbulkannya juga sangat luas bagi pembangunan dan kesejahteraan masyarakat, bahkan dapat melemahkan ketahanan nasional. Seiring berjalannya waktu, UU No. 9 Tahun 1976 diganti lagi dengan UU No. 22 Tahun 1997 sampai dengan munculnya UU Narkotika.

Pada bagian menimbang huruf e UU Narkotika dikemukakan bahwa tindak pidana narkotika telah bersifat transnasional yang dilakukan dengan menggunakan modus operandi yang tinggi, teknologi canggih, didukung oleh jaringan organisasi yang luas, dan sudah banyak menimbulkan korban, terutama di kalangan generasi muda bangsa yang sangat membahayakan kehidupan masyarakat, bangsa, dan negara, sehingga UU No. 22 Tahun 1997 sudah tidak sesuai lagi dengan perkembangan situasi dan kondisi yang berkembang untuk menanggulangi dan memberantas tindak pidana tersebut. Oleh sebab itu, dengan berlakunya UU Narkotika maka UU No. 22 Tahun 1997 dicabut dan dinyatakan tidak berlaku. ${ }^{9}$

UU Narkotika yang disahkan pada tanggal 14 September 2009 merupakan revisi dari UU No. 22 Tahun 1997. Pemerintah menilai UU No. 22 Tahun 1997 ini tidak dapat mencegah tindak pidana narkotika yang semakin meningkat secara kuantitatif maupun kualitatif serta bentuk kejahatannya yang terorganisir. Namun secara substansial, UU Narkotika tidak mengalami perubahan yang signifikan dibandingkan dengan UU terdahulu, kecuali penekanan pada ketentuan kewajiban rehabilitasi, penggunaan pidana yang berlebihan, dan kewenangan BNN yang lebih luas.

Mengenai perbuatan apa saja yang dapat dikriminalisasi dan apa sanksi yang dijatuhi terhadap subjek hukum dalam UU Narkotika, diatur dalam Bab XV dimulai dari Pasal 111 sampai Pasal 148 di bawah sub judul Ketentuan Pidana. Adapun hal-hal tersebut dibagi dalam beberapa bagian yaitu:

Pertama, tindak pidana yang berkaitan dengan penggolongan narkotika, dan precursor narkotika yang meliputi:

1) Menanam, memelihara, memiliki, menyimpan, menguasai, menyediakan narkotika golongan I dalam bentuk tanaman, dan narkotika golongan II bukan tanaman; 
2) pengadaan dan peredaran narkotika golongan I, II, dan golongan III, yang tidak menaati ketentuan perundang-undang yang berlaku, seperti: memproduksi, mengimpor, mengekspor, atau menyalurkan narkotika golongan I, narkotika golongan II, narkotika golongan III.

Kedua, tindak pidana yang berkaitan dengan menawarkan untuk dijual, menjual, membeli, menerima, menjadi perantara dalam jual beli, menukar, atau menyerahkan narkotika golongan I, narkotika golongan II, narkotika golongan III. Ketiga, tindak pidana yang berkaitan dengan membawa, mengirim, mengangkut, atau mentransit narkotika golongan I, narkotika golongan II, narkotika golongan III. Keempat, tindak pidana yang berkaitan dengan menggunakan narkotika golongan I terhadap orang lain, atau memberikan narkotika untuk digunakan orang lain, dan setiap penyalahgunaan narkotika golongan I, golongan II, dan golongan III bagi diri sendiri.

\section{Upaya Unit Narkoba Polres Halmahera Utara dalam Menanggulangi Kejahatan Narkotika}

Setelah melakukan penelitian di unit narkoba yang berada di bawah Satreskrim Polres Halmahera Utara, berikut diperoleh data tindak pidana narkoba selama 5 (lima) tahun terakhir yang dijadikan data untuk menganalisis upaya Polres Halmahera Utara dan implementasi UU Narkotika.

Tabe1 1.1. Data Tindak Pidana Narkotika di Polres Halmahera Utara

\begin{tabular}{|c|c|c|c|c|c|}
\hline $\begin{array}{l}\text { Periode } \\
\text { Tahun }\end{array}$ & Gol. \& Jenis Narkotika & $\begin{array}{l}\text { Pendi } \\
\text { dikan }\end{array}$ & $\begin{array}{l}\text { Peker- } \\
\text { jaan }\end{array}$ & $\begin{array}{l}\text { Jumlah } \\
\text { Tersangka }\end{array}$ & $\begin{array}{c}\text { Jumlah } \\
\text { Kasus }\end{array}$ \\
\hline 2013 & $\begin{array}{l}\text { Gol. } 1 \text { Bukan Tanaman } \\
\text { (Shabu-Shabu/Amfetamina) }\end{array}$ & SMA & $\begin{array}{l}\text { Wira- } \\
\text { swasta }\end{array}$ & 1 orang & 1 Kasus \\
\hline 2014 & $\begin{array}{l}\text { Gol. } 1 \text { Bukan Tanaman } \\
\text { (Shabu-Shabu/Amfetamina) }\end{array}$ & SMA & $\begin{array}{l}\text { Wira- } \\
\text { swasta }\end{array}$ & 1 orang & 1 Kasus \\
\hline 2015 & $\begin{array}{lcc}\text { Gol. } & 1 & \text { Tanaman } \\
\text { (Ganja/Cannabis) } & \end{array}$ & SMA & $\begin{array}{l}\text { Maha- } \\
\text { siswa }\end{array}$ & 3 orang & 1 Kasus \\
\hline 2017 & $\begin{array}{l}\text { Gol. 1 Bukan Tanaman } \\
\text { (Shabu- } \\
\text { Shabu/Metamfetamina) }\end{array}$ & $\begin{array}{l}\text { SMP } \\
\text { dan } \\
\text { SMA }\end{array}$ & $\begin{array}{l}\text { Wira- } \\
\text { swasta }\end{array}$ & 4 orang & 2 Kasus \\
\hline & & S1 & PNS & & \\
\hline 2018 & $\begin{array}{l}\text { Gol. } 1 \text { Bukan Tanaman } \\
\text { (Shabu- } \\
\text { Shabu/Metamfetamina) }\end{array}$ & SMA & $\begin{array}{c}\text { Politisi, } \\
\text { Wira- } \\
\text { swasta, } \\
\text { PNS, } \\
\text { Mahasis } \\
\text { wa, IRT }\end{array}$ & 14 Orang & 7 Kasus \\
\hline & & SMP & $\begin{array}{l}\text { Wira- } \\
\text { swasta }\end{array}$ & & \\
\hline \multicolumn{4}{|c|}{ TOTAL } & 23 Orang & 12 Kasus \\
\hline
\end{tabular}


Data pada tabel tersebut di atas menunjukan bahwa kasus narkoba yang terjadi di Kabupaten Halmahera Utara cenderung mengalami peningkatan hingga tahun terakhir yakni Tahun 2018 dengan jumlah kasus sebanyak 7 kasus. Selain itu, kasus narkoba di Kabupaten Halmahera Utara telah merasuki semua kalangan baik pelajar (SMP dan SMA), mahasiswa, IRT, PNS, politisi dan wiraswasta. Melalui data ini, maka semua pihak sudah harus waspada terkait bahaya narkotika yang sudah masuk dan menyebar di wilayah Kabupaten Halmahera Utara meskipun untuk skala nasional, Kabupaten Halmahera Utara belum masuk kategori darurat narkotika. Tetapi apapun itu, pencegahan dan pemberantasan sudah harus dan perlu dilakukan sejak dini.

Polri merupakan suatu institusi yang dibentuk dengan UU Kepolisian dengan tugas dan tanggung jawab melindungi, mengayomi masyarakat dan juga terlibat langsung dalam penegakan hukum. Pasal 13 UU ini menyatakan tugas pokok Polri adalah:

a. Memelihara keamanan dan ketertiban masyarakat.

b. Menegakkan hukum.

c. Memberikan perlindungan, pengayoman dan pelayanan kepada masyarakat.

Bertolak dari ketiga tugas pokok Polri tersebut, tumpuan negara, bangsa dan masyarakat terletak sepenuhnya di pundak kepolisian. Namun, tugas pokok tersebut sering belum mencapai kesempurnaan disebabkan beberapa faktor antara lain :

1. Terbatasnya anggota Polri.
2. Minimnya sarana pendukung yang menopang kepolisian dalam menjalankan tugasnya.

3. Sumber daya manusia yang masih relatif kurang.

4. Minimnya anggaran yang diberikan kepada institusi kepolisian.

Menurut data yang peroleh saat penelitian, di Polres Halmahera Utara khususnya pada satreskrim terdapat 4 (empat) unit yaitu unit 1 (satu) bagian Reserse Umum, unit 2 (dua) bagian Tindak Pidana Tertentu, unit 3 (tiga) bagian Tindak Pidana Korupsi dan unit 4 (empat) bagian Perlindungan Perempuan dan Anak. Dari unit-unit tersebut, unit narkotika masuk pada unit dua atau unit Tindak Pidana Tertentu dengan total jumlah anggota reskrim sebanyak 25 (dua puluh lima) orang dan yang berkualifikasi sebagai penyidik sebanyak 2 (dua) orang. Jumlah tersebut masih sangat sedikit untuk sebuah proses penegakan hukum di Kabupaten Halmahera Utara.

Dalam proses penegakan hukum, perlu diperhatikan kebijakan kriminal (criminal policy), dimana upaya penanggulangan dan pencegahan kejahatan perlu digunakan pendekatan integral yaitu perpaduan antara sarana penal dan non-penal, sebagaimana politik kriminal yang terkandung dalam Pasal-Pasal UU Narkotika. ${ }^{10}$ Sarana penal yakni melalui kebijakan hukum pidana sebagaimana ancaman sanksi dalam perundang-undangan. Sementara sarana non-penal adalah sarana non hukum pidana, yang dapat berupa kebijakan ekonomi, sosial, budaya, agama pendidikan teknologi dan lainnya. Upaya penanggulangan dan

10 Indah Lestari dan Sri Endah Wahyuningsih, 'Penegakan Hukum Pidana Terhadap Pengguna Narkoba di Polda Jateng' (2017) 12 (3) Jurnal Hukum Khaira Ummah 601, 603. 
pencegahan kejahatan narkotika membutuhkan pendekatan integral dikarenakan hukum pidana tidak akan mampu menjadi satu-satunya sarana yang dapat digunakan dalam upaya penanggulangan kejahatan narkotika yang begitu kompleks terjadi di masyarakat. Selain itu, berbagai upaya preventif melalui pendekatan agama, budaya, sosial, pendidikan, ekonomi dan lainnya perlu untuk dimaksimalkan dibandingkan pendekatan hukum yang bersifat represif.

Tujuan dibentuknya unit narkoba Polres Halmahera Utara adalah untuk meningkatkan koordinasi pelaksanaan, pencegahan, pemberantasan, penyalahgunaan dan peredaran gelap narkotika di wilayah hukum Polres Halmahera Utara. Dengan melihat beberapa kasus narkotika yang terjadi di Halmahera Utara itu artinya Halmahera Utara cepat atau lambat akan menjadi daerah yang strategis untuk kejahatan narkotika, ditambah lagi letak geografis Halmahera Utara yang mudah diakses melalui jalur laut, darat dan udara dengan mudah.

Hal yang dilakukan unit narkoba Polres Halmahera Utara selama ini dalam melakukan penegakan hukum terkait kejahatan narkotika menurut Bripka Iskandar ${ }^{11}$ sebagai Kepala Unit 2 (dua) Polres Halmahera Utara diantaranya dilakukan melalui operasi patroli, razia, dan juga sosialisasi ke sekolah-sekolah.

Unit narkoba memiliki fungsi dan tugas tersendiri untuk menjalankan kewajibannya. Fungsi Polri khususnya unit narkotika yaitu menjaga ketertiban, kemanan, memberikan perlindungan, pengayoman terhadap mas- yarakat dengan cara menegakan hukum dan peraturan yang berlaku. Sedangkan tugasnya adalah menyelenggarakan atau membina fungsi penyelidikan dan penyidikan kejahatan narkotika dan obat berbahaya lainnya, termasuk penyuluhan dan pembinaan dalam rangka pencegahan dan rehabilitasi korban penyalahgunaan narkotika.

Dalam 5 (lima) tahun terakhir sebagaimana data yang telah diuraikan sebelumnya, Polres Halmahera Utara paling tidak berhasil mengungkap 12 (dua belas) kasus narkotika dengan total 23 (dua puluh tiga) orang tersangka yang semuanya beragam jenis narkotikanya. Setelah melakukan penangkapan, hal yang pertama yang dilakukan adalah melakukan pemeriksaan urin yang bersangkutan di Laboratorium Rumah Sakit Bethesda Tobelo. Ini merupakan hasil kerja sama antara Polres Halmahera Utara dengan Rumah Sakit Bethesda Tobelo. Setelah itu, jika ada potensi para tersangka harus direhabilitasi, maka Polres akan bekerja sama dengan BNN Kabupaten Halmahera Utara untuk melakukan proses rehabilitasi.

Dalam melakukan penyidikan atas tersangka yang telah ditahan, sering kali penyidik mengalami banyak kesulitan karena jumlah personil penyidik pada unit narkoba yang masih sangat sedikit dan kurangnya penyidik yang memiliki keahlian khusus di bidang narkotika. Seperti telah dijelaskan bahwa unit narkotika Polres Halmahera Utara masih berada di bawah satreskrim sehingga penyidiknya bisa berganti-gantian dan hal ini mempersulit dan memper-

11 Wawancara dengan Iskandar, Kepala Unit 2, Polres Halmahera Utara (Halmahera Utara, 30 Maret 2019). 
lambat proses penyidikan. Hal demikian sejalan dengan apa yang dikatakan AKP. Rusli Mangoda dalam wawancara terkait tugas dan fungsi reskrim. Rusli mengatakan bahwa jumlah penyidik pada unit narkotika hanya 2 (dua) orang dan yang lainnya hanya berstatus penyidik pembantu sebanyak 23 (dua puluh tiga) orang. ${ }^{12}$

Bahaya narkotika di Kabupaten Halmahera Utara telah merasuki berbagai kalangan dan latar belakang profesi pekerjaan dengan demikian diperlukan upaya yang lebih giat lagi dalam memberantas dan mencegah terjadinya kejahatan narkotika. Polres Halmahera Utara lebih khususnya unit narkotika dalam memberantas dan menanggulangi kejahatan narkotika memiliki beberapa program preempitif, program preventif, dan program represif. Program-program tersebut diuraikan sebagai berikut:

a. Program Pre-empitif (Pembinaan)

Upaya pre-empitif yang dilakukan adalah mulai dari kegiatankegiatan edukasi dengan sasaran menghilangkan faktor-faktor penyebab yang menjadi pendorong dan faktor peluang yang biasa disebut faktor korelatif krimonogen dari kejahatan tersebut. Sasaran yang hendak dicapai adalah terbinanya dan tercapainya suatu kondisi perilaku dan norma hidup bebas dari narkotika. Hal tersebut juga ditegaskan Subagyo $^{13}$ bahwa program preempitif merupakan program pembinaan yang ditujukan kepada masyarakat yang belum memakai bahkan belum mengenal narko- tika. Dalam melaksanakan program pre-empitif ini dapat dilakukan dengan mengadakan berbagai bentuk kegiatan yang meliputi pelatihan, dialog interaktif, kegiatan olahraga, dan sosialisasi bagi semua kalangan terutama di sekolah-sekolah. Hal semacam ini pernah dilakukan oleh Polres Halmahera Utara bekerja sama dengan Prodi Hukum Universitas Halmahera.

b. Program Preventif

Dengan adanya Pasal 14 ayat (1) huruf i UU Kepolisian yang menjadi dasar hukum pelaksanaan upaya preventif oleh Polisi, maka dalam memberantas penyalahgunaan berbagai jenis narkotika kepolisian dituntut dapat melaksanakan program preventif yang salah satu tujuannya mencegah meluasnya penyalahgunaan berbagai jenis narkoba di kalangan masyarakat. Langkahlangkah pencegahan ini sudah dilakukan oleh unit narkotika Polres Halmahera Utara melalui penyuluhan dan razia.

c. Program Represif (Penindakan)

Program represif ini telah dilakukan oleh Polres Halmahera Utara melalui unit narkotika yang berada di bawah satreskrim dalam memberantas berbagai bentuk kejahatan narkotika dalam wilayah Kabupaten Halmahera Utara. Pelaksanaan program represif dimulai dari tahapan penyelidikan, penyidikan sampai

\footnotetext{
12 Wawancara dengan Rusli Mangoda, Kepala Satreskrim, Polres Halmahera Utara (Polres Halmahera Utara, 4 Maret 2019).

13 Subagyo Partodiharjo, Kenali Narkoba dan Musuhi Penyalahgunaannya (Esensi 2006) 100.
} 
dengan penangkapan yang

berfungsi untuk memberikan hukuman kepada pengedar dan penyalahgunaan agar mendapat efek jera.

Penyelidikan merupakan proses awal untuk mengungkap suatu tindak pidana atau berbagai penyimpangan yang terjadi di lingkungan masyarakat termasuk penyalahgunaan narkotika, seperti yang tercantum dalam Pasal 1 butir 5 Kitab Undang-Undang Hukum Acara Pidana yang menyebut bahwa penyelidikan adalah serangkaian tindakan penyelidik untuk mencari dan menemukan suatu peristiwa yang diduga sebagai tindak pidana guna menentukan dapat atau tidaknya dilakukan penyidikan menurut cara yang diatur dalam UU.

Selama ini unit narkotika Polres Halmahera Utara dinilai berhasil dalam melakukan upaya pencegahan dan pemberantasan narkotika. Hal mana dibuktikan bahwa hampir setiap 4-5 bulan berjalan pasti ditangkap pelaku narkotika meskipun dalam skala kecil. Selain itu, keberhasilan unit narkotika Polres Halmahera Utara juga terlihat pada hampir semua kasus yang dilakukan penyidikan, diproses sampai pada tahapan penuntutan dan bahkan sampai ke pengadilan dan pelaksanaan putusan pengadilan serta proses rehabilitasi di lembaga pemasyarakatan (lapas).

Berdasarkan kajian efektifitas hukum yang dikemukakan Soetjipto Rahardjo terkait bekerjanya hukum, apabila dikaitkan dengan peran dan fungsi unit narkotika Polres Halmahera Utara dalam menanggulangi dan memberantas kejahatan narkotika di Kabupaten Halmahera Utara maka: Pertama, unit narkotika Polres Halmahera Utara telah melakukan berbagai upaya dalam rangka menanggulangi dan memberantas kejahatan narkotika di wilayah hukum Polres Halmahera Utara yakni dengan cara melakukan sosialisasi, penyuluhan, bimbingan kepada masyarakat terkait peraturan dan regulasi yang berkaitan dengan narkotika. Kedua, unit narkotika Polres Halmahera Utara telah bekerja sama dengan beberapa instansi untuk sama-sama memberantas kejahatan narkotika misalnya kerja sama dengan Pengadilan Negeri Tobelo, Kejaksaan Negeri Halmahera Utara, Lapas Kelas II Tobelo, Rumah Sakit Bethesada, BNN Halmahera Utara dan Dinas Kesehatan Halmahera Utara. Kerja sama dibangun dalam melaksanakan fungsi dan tugas masing-masing namun bermuara pada satu tujuan yakni menanggulangi kejahatan nerkotika di wilayah hukum Polres Halmahera Utara. Ketiga, unit narkotika Polres Halmahera Utara tetap berperan dalam hal penindakan represif jika ada laporan masyarakat tentang dugaan kejahatan narkotika, unit narkoba langsung merespon cepat dengan cara memulai tahapan penyelidikan, penyidikan sampai pelimpahan perkara ke kejaksaan. Keempat, terkait dengan hal penegakan hukum atau bekerjanya hukum antara apa yang tertulis dengan kenyataan yang terjadi di lapangan, unit narkotika Polres Halmahera Utara dalam menjalankan tugas dan perannya tetap berpatokan pada beberapa regulasi peraturan yang telah ada seperti UU No. 8 Tahun 1981, UU Kepolisian, UU Narkotika dan peraturan terkait lainnya.

Selain itu, dalam upaya unit narkotika Polres Halmahera Utara menanggulangi kejahatan narkotika, menurut G. Peter Hoefnagels dalam 
Barda Nawawi Arief ${ }^{14}$ menyebutkan bahwa upaya penanggulangan kejahatan dapat ditempuh dengan:

1. Penerapan hukum pidana (criminal law application);

2. Pencegahan tanpa pidana (prevention without punishment);

3. Mempengaruhi pendangan masyarakat mengenai kejahatan dan pemidanaan lewat media massa (influencing views of society on crime and punishment with mass media).

Hal sebagaimana diuraikan tersebut sebagian besar telah dilaksanakan oleh unit narkotika Polres Halmahera Utara. Hal itu terbukti misalnya untuk penerapan hukum pidana (criminal law application), bahwa sebagian besar tersangka yang ditangkap unit narkotika Polres Halmahera Utara sejak 5 (lima) tahun terakhir disidik dan dilimpahkan perkaranya ke kejaksaan untuk seterusnya di proses dalam persidangan di pengadilan pidana. Sementara itu, untuk pencegahan tanpa pidana (prevention without punishment), juga telah dilaksanakan unit narkotika Polres Halmahera Utara dengan cara memberikan sosialisasi, penyuluhan, dan bimbingan terkait bahaya narkotika kepada masyarakat dan hal seperti ini sudah masuk dan menjadi program unit narkotika Polres Halmahera Utara. Selain itu terkait dengan hal ini, ada juga beberapa tersangka yang tidak diproses secara hukum melainkan dilakukan rehabilitasi. Selanjutnya terkait upaya penanggulangan kejahatan yang ketiga yakni mempengaruhi pendangan masyarakat mengenai kejahatan dan pemidanaan lewat media massa (influencing views of society on crime and punishment with mass media). Hal inipun sudah selalu dilakukan oleh unit narkotika Polres Halmahera Utara dengan cara memasang berbagai iklan di koran, radio dan spanduk yang berisikan pesan tentang bahaya penggunaan dan penyalahgunaan narkotika.

\section{Penegakan Hukum Kejahatan Narkotika}

Sebagai suatu negara yang menganut sistem hukum Eropa Kontinental, penegakan hukum seakan-akan dipandang sebagai penegakan UU semata. Hal tersebut dapat dipahami karena selama ini, proses penegakan hukum hanya berorientasi pada setiap orang yang terbukti melanggar norma atau UU, ditangkap dan diadili melalui suatu proses peradilan dan dianggap masalahnya selesai.

Tentunya pemahaman tentang konsep penegakan hukum yang demikian adalah sangat sempit adanya. Penegakan hukum tidak semata-mata dipandang sebagai penegakan norma perundang-undangan belaka tetapi lebih dari itu. Hukum merupakan sarana yang di dalamnya terkandung nilai-nilai atau konsepkonsep tentang keadilan, kebenaran, kemanfaatan dan lain sebagainya. Sehingga, kandungan hukum tersebut bersifat abstrak yang oleh Satjipto Rahardjo, menyebut penegakan hukum pada hakikatnya merupakan penegakan ide-ide atau konsepkonsep yang abstrak itu. Penegakan hukum merupakan usaha untuk mewujudkan ide-ide tersebut menjadi kenyataan. Sejalan dengan hal tersebut, Soerjono Soekanto menga-

14 Barda Nawawi Arief, Bunga Rampai Kebijakan Hukum Pidana (Cet. ke-2, Citra Aditya Bakti 2005) 43-44. 
takan bahwa penegakan hukum adalah kegiatan menyerasikan hubungan nilai-nilai yang terjabarkan di dalam kaidah-kaidah/pandanganpandangan nilai yang mantap dan mengejawantah dan sikap tindak sebagai rangkaian penjabaran nilai tahap akhir untuk menciptakan (sebagai 'social engineering'), memelihara dan mempertahankan (sebagai 'social control') kedamaian pergaulan hidup. 15

Jika hakikat penegakan hukum adalah untuk mewujudkan nilai-nilai keadilan dan kebenaran, maka sebenarnya penegakan hukum bukanlah semata-mata tugas dan tanggung jawab dari aparat penegak hukum saja melainkan tugas dan tanggung jawab setiap orang. Hal inilah yang oleh Ilhami Bisri disebutkan bahwa penegakan hukum merupakan usaha semua kekuatan bangsa, menjadi kewajiban kolektif semua komponen bangsa dan sekaligus merupakan ralat bahwa hukum hanya boleh ditegakan oleh golongan-golongan tertentu saja, seperti:

a. Aparatur negara yang memang ditugaskan dan diarahkan untuk itu, seperti polisi, jaksa, hakim, yang dalam dunia hukum disebut secara ideal sebagai the three musketers (tiga pendekar hukum) yang mempunyai fungsi yang berbeda-beda namun bermuara pada terciptanya hukum yang adil, tertib dan bermanfaat bagi semua manusia.

b. Pengacara/advokat yang memiliki fungsi advokasi dan mediasi bagi masyarakat baik yang bekerja secara individual maupun yang bergabung secara kolektif dalam lembaga-lembaga bantuan hukum.

c. Para eksekutif yang bertebaran di berbagai lahan pengabdian sejak dari pegawai pemerintah yang memiliki beraneka fungsi dan tugas kewajiban sampai kepada para penyelenggara yang memiliki kekuasaan politik (legislatif). ${ }^{16}$

Konsep penegakan hukum khususnya hukum pidana dalam hal terjadinya tindak pidana narkotika, apabila dilihat dari suatu proses kebijakan maka penegakan hukum pada hakikatnya merupakan penegakan kebijakan melalui beberapa tahap yang oleh Muladi membaginya ke dalam 3 (tiga) tahap, yaitu: Pertama, disebut tahap formulasi, yakni tahap penegakan hukum in abstracto oleh badan pembuat UU. Tahap ini disebut dengan tahap legislatif. Kedua, tahap aplikasi, yaitu tahap penerapan hukum pidana oleh aparat-aparat penegak hukum mulai dari kepolisian sampai pengadilan. Tahap kedua ini disebut juga dengan tahap kebijakan yudikatif. Ketiga, tahap eksekusi, yaitu tahap pelaksanaan hukum pidana secara konkrit oleh aparat penegak hukum. Tahap ini disebut juga tahap kebijakan eksekutif atau administratif. ${ }^{17}$

Penegakan hukum prinsipnya bertujuan untuk menciptakan kehidupan masyarakat yang harmonis dan kehidupan yang damai setelah pelaku dijatuhi pidana. Hal inilah sehingga Teguh Prasetyo mengatakan diperlukan suatu sistem hukum untuk

\footnotetext{
15 Soerjono Soekanto, Faktor-Faktor yang Mempengaruhi Penegakan Hukum (Rajawali Pers 1983) 13.

16 Ilhami Bisri, Sistem Hukum Indonesia, Prinsip-Prinsip \& Implementasi Hukum di Indonesia, (Cet. ke-5, RajaGrafindo Persada 2010) 128-129.

17 Muladi, Kapita Selekta Sistem Peradilan Pidana (Undip Semarang 1995) 13-14.
} 
mengaturnya. Carut marut sistem hukum yang dianut di Indonesia selama ini menjadikannya menawarkan sistem hukum Pancasila yang dipandang sesuai dengan nilai-nilai yang hidup dalam masyarakat Indonesia. ${ }^{18}$ Namun menurut Zainab Ompu ${ }^{19}$ untuk kejahatan narkotika, sanksi pidana atau hukuman dipersepsikan masyarakat sebagai imbalan atau pembalasan terhadap orang yang telah melakukan kejahatan. Oleh karena itu, hukuman yang diakui dalam realitas sosial masyarakat haruslah mengandung pembalasan.

Berdasarkan konsep penegakan hukum yang telah diuraikan tersebut, unit narkotika Polres Halmahera Utara dalam melakukan penanggulangan kejahatan narkotika di Kabupaten Halmahera Utara terdapat beberapa faktor penghambat penegakan hukum di antaranya faktor aparat penegak hukum. Biasanya ketika operasi atau razia dilakukan oleh unit narkotika Polres Halmahera Utara, ada oknumoknum penegak hukum tertentu yang membocorkan informasi kepada para pelaku tersebut sehingga para pelaku sudah mengetahui informasi lebih dahulu dan sering kali operasi atau razia tidak membuahkan hasil apaapa. Faktor penghambat berikutnya adalah minimnya biaya penyidikan dan operasional yang tersedia sehingga aparat penegak hukum dalam hal ini unit narkotika Polres Halmahera Utara seringkali tidak maksimal dalam melakukan patroli antisipasi disebabkan karena letak geografis Kabupaten Halmahera Utara yang harus membutuhkan biaya operasional yang cukup tinggi. Contohnya untuk melakukan penyidikan atau patroli untuk wilayah Loloda harus menggunakan jalur air. Selain itu, terdapat juga faktor tumpang tindih kewena-ngan yang ada di internal kepolisian. Seperti sudah dijelaskan bahwa unit narkoba masih bernaung di bawah Satreskrim Polres Halmahera Utara dan belum dibentuk satuan narkotika tersendiri sehingga seringkali tim anggota penyidik berpindah-pindah yang mengakibatkan proses penegakan hukum menjadi terlambat atau slow respons dalam menangani perkara narkotika.

Seperti diketahui bahwa kejahatan narkotika merupakan kejahatan internasional (international crime), kejahatan yang terorganisir (organize crime), mempunyai jaringan yang luas, mempunyai dukungan dana yang besar dan sudah menggunakan teknologi yang canggih. Dengan demikian diperlukan kerja sama semua pihak termasuk masyarakat dalam proses penegakan hukum. ${ }^{20}$ Akan tetapi, selain aparat penegak hukum, masyarakat sendiri juga merupakan faktor penghambat dalam proses penegakan tindak pidana narkotika. Dalam beberapa kali operasi yang dilakukan Polres Halmahera Utara, kebanyakan masyarakat yang tinggal di lingkungan objek sasaran acuh tak acuh dan ada juga yang malah menyembunyikan informasi dari aparat sehingga aparat seringkali mengalami kesulitan di lapangan sebagai akibat dari kurang

18 Teguh Prasetyo, Hukum dan Sistem Hukum Berdasarkan Pancasila (Cet. pertama, Media Perkasa 2013) 39.

19 Zainab Ompu, 'Persepsi Penerapan Sanksi Pidana Terhadap Pelaku Tindak Pidana Narkotika, Studi Pada Wilayah Hukum PN Kelas 1 A Tanjung Karang' (2012) 41 (2) Jurnal MasalahMasalah Hukum 167, 173.

20 Fransiska Eleanora, 'Bahaya Penyalahgunaan Narkoba Serta Usaha Pencegahan dan Penanggulangannya (Suatu Tinjauan Teoritis)' (2011) 25 (1) Jurnal Hukum 439, 440. 
nya tingkat partisipasi masyarakat dalam proses penegakan hukum. Hal yang telah diuraikan ini dibenarkan oleh Bripka Iskandar ${ }^{21}$ yang menyebut bahwa dari aspek peraturan perundang-undangan narkotika sudah baik, namun faktor yang seringkali menjadi penghambat adalah berasal dari internal penegak hukum sendiri dan dari masyarakat yang acuh berpartisipasi dalam penegakan hukum.

\section{PENUTUP}

Kesimpulan yang diambil dari pembahasan yang telah diuraikan sebelumnya yakni:

Pertama, upaya yang dilakukan Polres Halmahera Utara dalam hal ini unit narkotika dalam menanggulangi kejahatan narkotika di Kabupaten Halmahera Utara selama ini yakni dengan menggunakan sarana penal dan non-penal. Sarana penal dapat terlihat dari data hasil penelitian yang telah diuraikan sebelumnya dimana beberapa perkara diproses sampai pada tahapan pelimpahan perkara ke kejaksaan. Sementara untuk sarana non-penal, unit narkotika Polres Halmahera Utara telah melakukan kerja sama dengan beberapa instansi untuk upaya pemulihan maupun upaya pencegahan sebelum ataupun setelah terjadinya tindak pidana narkotika. Misalnya untuk beberapa kasus rehabilitasi, Polres Halmahera Utara melakukan kerja sama dengan BNN Kabupaten Halmahera Utara dan rumah sakit Bethesda Tobelo. Untuk tindak pencegahan yang dilakukan melalui patroli dan jam malam serta razia tempat-tempat nongkrong, razia kendaraan dan sosialisasi pencegahan serta bahaya narkotika ke sekolahsekolah merupakan hasil kerja sama Polres Halmahera Utara dengan Program studi Hukum Universitas Halmahera.

Kedua, faktor penghambat penegakan hukum kejahatan narkotika di Kabupaten Halmahera Utara yakni:

1. Kurangnya personil kepolisian di satreskrim. Personil hanya berjumlah 25 (dua puluh lima) orang dengan jumlah penyidik berkualifikasi hanya 2 (dua) orang yang sekaligus merangkap sebagai anggota reskrim umum. Selain personil yang terbatas, Polres Halmahera Utara juga belum memiliki satuan narkoba yang menyebabkan proses penegakan hukum yang sifatnya cepat dan responsif menjadi terhambat.

2. Sarana dan fasilitas yang kurang memadai. Seperti diketahui wilayah Polres Halmahera Utara sangat luas meliputi wilayah Kao hingga wilayah Loloda. Dengan wilayah yang luas ini maka untuk melakukan patroli ataupun razia dibutuhkan sarana yang memadai, terlebih lagi wilayah Loloda yang harus ditempuh dengan jalur laut karena akses jalan darat yang belum membaik.

3. Dari aspek internal penegak hukum sendiri seringkali membocorkan informasi sebelum razia dilakukan sehingga para terduga pelaku narkoba sudah lebih dahulu mengetahui informasi akan dilakukannya razia dan melarikan diri terlebih dahulu.

21 Iskandar, Kanit II bidang Nakotika, Polres Halmahera Utara (Halmahera Utara, 30 Maret 2019). 
DAFTAR PUSTAKA

\section{Buku}

Arief Barda N, Bunga Rampai Kebijakan Hukum Pidana (Cet. ke2, Citra Aditya Bakti 2005).

Bisri I, Sistem Hukum Indonesia, Prinsip-Prinsip \& Implementasi Hukum di Indonesia (Cet. ke-5, RajaGrafindo Persada 2010).

FR. Julianan L, Nengah Sutrisna W, Narkotika, Psikotropika dan Gangguan Jiwa (Nuha Medika 2013).

Marzuki Peter M, Penelitian Hukum (Kencana 2005).

Muladi, Kapita Selekta Sistem Peradilan Pidana (Undip Semarang 1995).

Nasution Bahder J, Metode Penelitian Ilmu Hukum (Cet. pertama, CV. Mandar Maju 2008).

Partodiharjo S, Kenali Narkoba dan Musuhi Penyalahgunaannya (Esensi 2006).

Prasetyo T, Hukum dan Sistem Hukum Berdasarkan Pancasila (Cet. pertama, Media Perkasa 2013).

Soekanto S, Faktor-Faktor Yang Mempengaruhi Penegakan Hukum (Rajawali Pers 1983).

Wahid A, Kriminologi dan Kejahatan Kontemporer (Fakultas Hukum Unisma 2002).

\section{Artikel Jurnal}

Eleanora F, 'Bahaya Penyalahgunaan Narkoba Serta Usaha Pencegahan dan Penanggulangannya (Suatu Tinjauan Teoritis)' (2011) 25 (1) Jurnal Hukum.

Lestari I, dan Wahyuningsih Sri E, 'Penegakan Hukum Pidana Terhadap Pengguna Narkoba di Polda Jateng' (2017) 12 (3) Jurnal Hukum Khaira Ummah.
Ompu Z, 'Persepsi Penerapan Sanksi Pidana Terhadap Pelaku Tindak Pidana Narkotika, Studi Pada Wilayah Hukum PN Kelas 1 A Tanjung Karang' (2012) 41 (2) Jurnal Masalah-Masalah Hukum.

Rahmadona E, 'Faktor yang Berhubungan dengan Penyalahgunaan Narkoba di RSJ. HB. Sa'anin' (2014) 8 (2) Jurnal Kesehatan Masyarakat Andalas.

Sudanto A, 'Penerapan Hukum Pidana Narkotika di Indonesia' (2017) 8 (1) ADIL: Jurnal Hukum.

\section{Website}

Anang Iskandar Anang, 'BNN Ingatkan 50 Orang Meninggal Setiap Hari Karena Narkoba' (Kemneterian Komunikasi dan Informatika Republik Indonesia, 30 April 2015) <https://kominfo.go.id/content/d etail/4883/bnn-ingatkan-50orang-meninggal-setiap-harikarenanarkoba/0/sorotan_media > diakses 10 Juli 2019.

Olis, 'Kasus Narkoba di Maluku Utara Ibarat Gunung Es' (Kumparan, 31 Mei 2019 2019) <https://kumpa ran.com/ceritamalukuutara/kasu s-narkoba-di-maluku-utara-ibara t-gunung-es-1rBeQnxGbt7> diakses 31 Mei 2019.

\section{Peraturan Perundang-Undangan}

Undang-Undang Nomor 8 Tahun 1981 tentang Kitab Undang-Undang Hukum Acara Pidana.

Undang-Undang Nomor 2 Tahun 2002 tentang Kepolisian Negara Republik Indonesia.

Undang-Undang Nomor 35 tahun 2009 tentang Narkotika. 